\title{
A maré em escrita em Mar Azul (2012), de Paloma Vidal
}

\author{
Karine Mathias Döll \\ Keli Cristina Pacheco ${ }^{2}$
}

\begin{abstract}
The present work aims to indicate a reading of the novel Mar azul (2012), written by Paloma Vidal, as from a dialogue with the possibilities of reading our contemporaneity, potentializing reflections on themes such as dictatorship, repression and violence against women. Divided into two sections, the first traces the chronological aspects of the novel to better understand its period, describes the profile of the characters narrated by the protagonist and relates the characteristics of the characters to the sign sea, aiming to identify the drawing of the marine sensations movements present in the novel. Then in the second section, we will dwell on the reading possibilities that give rise to a reflection between the novel and past/present political events.
\end{abstract}

Keywords: Feminist Criticism; contemporary textualities; Brazilian Literature.

Resumo: O presente trabalho tem como objetivo propor uma leitura do romance Mar azul (2012), escrito por Paloma Vidal, a partir de um diálogo com possibilidades de leitura da nossa contemporaneidade, potencializando reflexões acerca de temas tais como ditadura, repressão e violência contra a mulher. Dividido em duas seções, na primeira traçaremos aspectos cronológicos da obra a fim de melhor compreender o período de que trata, descreveremos o perfil das personagens narradas pela protagonista e relacionaremos as características das personagens ao próprio signo mar, objetivando identificar o desenho das sensações de movimentos aquosos/ marítimos presentes no romance. Já na segunda, nos deteremos às possibilidades de leitura que suscitem uma reflexão acerca das conexões entre o romance e acontecimentos políticos do passado/presente.

Palavras-chave: Crítica feminista; textualidades contemporâneas; Literatura Brasileira.

Los lugares y los rostros se graban en las entrañas y los huesos, cada zona del cuerpo tiene sus recuerdos. Alejandra Pizarnik

A intimidade era teatro. Ana Cristina Cesar

1 Mestranda em Estudos da Linguagem na Universidade Estadual de Ponta Grossa - UEPG. Licenciada em Letras Português-Inglês pela mesma instituição.

2 Doutora em Literatura pela Universidade Federal de Santa Catarina-UFSC. Professora adjunta do Departamento de Estudos da Linguagem da Universidade Estadual de Ponta Grossa-UEPG, e docente permanente do programa em Pós-graduação em Estudos da Linguagem-UEPG 


\section{Introdução}

O romance Mar azul (2012), escrito pela argentina quase brasileira, embora não-naturalizada, Paloma Vidal, sem dúvidas é um convite para adentrarmos águas mais profundas, e, por consequência, mais nebulosas, embora isso não signifique que permaneceremos submersos, sem ao menos nos darmos conta de que poderão existir aportes mais amenos dos quais seja possível vislumbrar até mesmo um certo azul que resplandece. Mas o que isso quer dizer? Os simbolismos que regem o título se apresentam justamente no físico do livro e das palavras, no ritmo "em destempo", numa contradança marítima que mareia, mas também faz flutuar; numa narrativa em passo de maré - ora alta, ora baixa e sobretudo diária.

Assim, a proposta que queremos desenvolver no presente artigo trata de possibilidades de leitura do romance em questão que dialoguem com possibilidades de leitura da nossa contemporaneidade, potencializando reflexões acerca de temas tais como ditadura, repressão e violência contra a mulher. Contudo, equivoca-se quem pensa que Mar $a z u l$, pelos temas então evocados, é capaz de assumir apenas um caráter de literatura de resistência, ou seja, literatura que tematize a ditadura e tão somente, ou mesmo de arte engajada. Ainda que o contexto ditatorial argentino em memória perpasse toda a obra e impulsione determinadas atitudes por parte de algumas personagens ou em relação a elas, ele figura tão só como pano de fundo para o desenvolvimento de outras tramas. Nesse sentido, se fôssemos pensar em Mar azul a partir de certo tipo de engajamento, seria pressupondo uma profunda vinculação dele com o seu tempo e com os fantasmas que ainda nos assombram, engendrando uma subjetivação permanente, refém de outras subjetividades. E se fôssemos pensar em algo ao qual ela resiste, seria aos próprios meandros da crítica literária que insiste em manter autoras mulheres e seus "problemas domésticos" à margem, enquanto algo menor, e (des)caracterizar a literatura escrita por elas como meramente "feminina", ao passo que nós sempre a entenderemos primeiramente e principalmente enquanto literatura.

Em decorrência dos apontamentos acima, vemos a literatura produzida por Paloma Vidal como associada a um fazer literário o qual ampara nosso presente histórico, desestabilizando-o, uma vez que, como já havia nos dito Rancière, "escrever a história e escrever histórias pertencem a um mesmo regime de verdade." (RANCIERE, 2009, p. 58), regime este que precisa o tempo todo ser colocado à prova em meio a tantos discursos que, em última instância, acabam por apenas nos deixar à deriva, sem direcionamento - tanto quanto é possível perceber também na narradora/protagonista de Mar azul, cujas perguntas direcionadas aos fatos ela nem se atreve a fazer. Dessa forma, escancarar uma falsa ideia de simples intimismo sugerida pela obra, ou ainda um pseudoviés diarístico que corresponderia às inquietações da mesma, seria muito pouco ao largo de tamanho alcance que resulta dessa figuração da intimidade que desborda as fronteiras entre interioridade e exterioridade, alcançando o campo do afeto, como dirá Luciana Di Leone, em Poesia e escolhas afetivas. Há muito discutimos que "o pessoal é político", e talvez o romance de que vamos tratar traga esta máxima feminista como chave de leitura possível, já que poderiam alguns pensar no movimento de escrita da narradora, no verso das páginas produzidas por seu pai, como uma espécie de terapia que a recolocaria numa posição privilegiada diante de seu próprio eu que se enuncia, o que não acontece. Se o capítulo 14 do 
romance começa pelas afirmações: "Isto não é um diário, nem uma carta, nem uma autobiografia, nem qualquer outro modo de escrita íntima. Só escrevo porque ele escreveu do outro lado." (VIDAL, 2012, p. 74), acreditamos nesta narradora na medida do possível, não porque nos colocamos na posição de leitores-modelo da obra, mas porque sabemos que mesmo sendo um diário, ou uma carta, ou uma autobiografia, ou qualquer outro modo de escrita íntima, esta escrita já vem imbricada no emaranhado de verdades não-lineares proposto pela autora, e a verdade só não será política se não se quiser problematizada, o que a tornará, em contrapartida, duplamente politizada. Ou, como bem apontou Rita Terezinha Schmidt em relação às críticas que erguiam-se em torno do surgimento do GT "A mulher na literatura", as quais desmereciam e subestimavam o trabalho das pesquisadoras envolvidas por considerá-lo mera panfletagem política a despeito dos atributos estéticos da grande literatura: "como se a forma estética pudesse ser depurada de sua política." (SCHMIDT, 2017, p. 23)

Mas talvez tenhamos nos antecipado e é preciso incrementar essas palavras soltas sobre Mar azul com algum tipo de enredo, o qual se faz única e exclusivamente pela memória da protagonista. Sabemos que seu pai a abandonara quando ainda muito nova, por volta de treze anos, e que nunca pôde conhecer sua mãe, a não ser por foto. Passou a morar na casa da amiga Vicky e de sua mãe, até que Vicky desaparecera, levada pelo regime militar no ano de 1976. Três meses depois, segundo a narradora, ela pega um ônibus e vai para o norte, rumo ao Brasil que era onde seu pai havia se instalado depois de deixar ela e a Argentina para atrás, com o intuito de "construir uma nova capital num outro país" (VIDAL, 2012, p. 119), exatamente em 1956. Já em terras tupiniquins, é narrado um telefonema feito pela vizinha de seu pai avisando que ele havia falecido e ao se deslocar até a capital para constatar a ausência definitiva anunciada, descobre no apartamento em Brasília uma caixa cheia de cadernos que ela toma para si como uma espécie de "tesouro às avessas" e passa a escrever no verso de suas folhas, "minha tinta se confunde com a dele." (VIDAL, 2012, p. 69), com o objetivo de talvez chegar a uma lembrança, como ela própria sugere no capítulo 12. Contudo, e falando em lembranças, enquanto seu pai escrevia para não esquecer, uma vez que parece ter lhe acometido o mal de Alzheimer ou qualquer condição que lhe consumisse a memória, ela parece escrever para não lembrar e, não lembrando, acaba situando sua narrativa num ultrapresente, como proposto por Tamara Kamenszain, "que não quer perder nada, mas tampouco quer ganhar alguma densidade” (2016, [n.p.])3. Tem-se aqui, então, o início de nossa análise.

Só que antes de darmos início, é preciso lembrar: o mar azul não apenas envolve o romance enquanto alegoria. Ele é a própria memória. É para dentro do mar azul que vamos e é lá que ficaremos por um tempo, até que a narradora saia e nos leve junto. Se é que é possível sair. Talvez nem mesmo indo contra a corrente.

\section{Da maré ao mar: aspectos da obra}

Dividiremos esta seção em três momentos. No primeiro, tentaremos traçar aspectos cronológicos da obra a fim de potencializar reflexões acerca do período de que trata. Num segundo momento, descreveremos o perfil das personagens narradas pela protagonista à luz da cronologia ora apresentada. Por fim, relacionaremos as características das perso-

3 “que no quiere perder nada pero tampoco quiere ganar ninguna densidad." (2016, [n.p.], tradução nossa) 
nagens ao próprio signo mar e a sua simbologia, objetivando identificar o desenho das sensações de movimentos aquosos/marítimos presentes no romance.

Embora em Mar azul os fatos não nos sejam apresentados com base numa sequência cronológica precisa, destacamos a importância de evidenciar algumas marcas temporais previstas pela autora, uma vez que as constantes discretas alusões a um regime repressivo, ainda que em momento algum se encontre nestes termos ou em termos semelhantes, dão sentido à atmosfera segundo a qual o texto está impregnado. Como um exemplo dessa discrição, nas linhas abaixo vemos um comentário feito pela narradora no capítulo 20, quando na viagem de vinda ao Brasil descreve o encontro com um passageiro que vinha ao seu lado dentro do ônibus:

Vestia uma camiseta azul-claro e uma calça branca, o que me pareceu inusitado para quem vai viajar tantas horas de ônibus e me fez comentar, quando já tínhamos nos tornado amigos, que ele havia se fantasiado com a bandeira da pátria. Aunque no se lo merece, ele comentou, e eu me calei, pois ainda não éramos amigos o suficiente para seguir aquela conversa. (VIDAL, 2012, p. 89)

É importante destacar também que em momento algum do romance a autora cita os nomes dos países em questão, deixando a cargo dos leitores perceber que talvez o mérito maior da obra não esteja situado na representação de um país num determinado período de sua história, mas, antes, na representação dos efeitos da arbitrariedade da vida e de escolhas alheias às dela na subsequente produção e descrição de estados de ânimo, os quais poderiam ocorrer a qualquer pessoa, em qualquer lugar. E contextos repressivos, sem dúvidas, partem de arbitrariedades. Nesse sentido, vemos o desaparecimento de sua amiga, Vicky, como um primeiro marco temporal na obra a ser destacado, visto que ocorre no dia 26 de junho de 1976. Embora os governos militares argentinos tenham se estendido, com algumas tentativas mais democráticas que os deixavam em suspenso, do ano de 1955, com a queda de Perón, até dezembro de 1983, no ano de 1976 “a repressão com características hediondas apenas começava", segundo Boris Fausto e Fernando J. Devoto, “[...] alcançando militantes políticos democráticos, sacerdotes, intelectuais, jornalistas, defensores dos direitos humanos, numa demonstração de que o governo pretendia aterrorizar a população e abafar qualquer atividade social ou política." (FAUSTO; DEVOTO, 2004, p. 456) De início, não sabemos com exatidão quais eram as atividades desenvolvidas por Vicky e a narradora, no entanto sabíamos que seu livre-arbítrio poderia estar ameaçado por apresentarem características mais "subversivas" em relação ao meio em que viviam e eram criadas. Sabemos de antemão que a mãe de Vicky era mãe solteira e, segundo as palavras da própria narradora sobre a primeira vez que esteve em sua casa para brincar com Vicky e a conheceu: "Ela usava short. Eu nunca havia visto uma mãe de short. As mães das outras meninas pareciam mães da mãe de Vicky. Em casa usavam batas com flores." (VIDAL, 2012, p. 64) Ou ainda, no prólogo que antecipa o capítulo 1, no qual se apresentam vários fragmentos de diálogos entre a narradora e Vicky (falaremos melhor deles mais adiante), um deles trata dos livros que a mãe de Vicky possuía em sua casa:

- Que livro é esse?

- Achei na biblioteca da sua mãe.

- Cuardernos de infancia. 
- Ela tem vários livros dentro do armário.

- Que ela nunca lê.

- Vai ver que ela le escondida.

- Que ideia, por que você tá falando isso?

- Sei lá, por que ela esconde os livros?

- Não estão escondidos, é pra não pegar pó. É sério, ela não quer que estraguem, sei lá, ela tem uma coisa com isso. São que nem bibelôs. (VIDAL, 2012, p. 25)

Salta aos olhos que Vidal tenha escolhido uma obra de Norah Lange (1905-1972) a fim de delimitar características para suas personagens, uma vez que Lange, nascida em Buenos Aires, teve forte presença no meio intelectual da época na capital argentina, mesmo que não fosse comum para uma mulher se dedicar à literatura ativamente, como foi o seu caso. Ademais, a autora também ficou conhecida por ser o amor frustrado de Jorge Luis Borges, que o rejeitou. Tais informações, que podem parecer acessórias num primeiro momento, mostram-se imprescindíveis para entender o contexto repressivo enunciado e, em paralelo, mas não menos significativo, a dimensão psicológica de um relacionamento abusivo vivido pela narradora quando ainda adolescente, com apenas 13 anos de idade, como fica claro num fragmento de diálogo anterior ao acima transcrito. Dessa forma, fica possível admitir que tanto a narradora quanto Vicky e sua mãe eram ligadas, de alguma maneira, às classes mais intelectualizadas e, por conseguinte, mais politizadas, mas lá para depois da metade do romance a narradora finalmente nos indica o motivo concreto do desaparecimento da amiga: "O quanto Vicky sabia era surpreendente. [...] Por isso foi tão difícil depois aceitar que ela estivesse arriscando a própria vida na militância." (VIDAL, 2012, p. 122) e esclarece também sobre suas pretensões: "O teatro tinha que cumprir uma missão e, como atriz, se colocaria inteiramente a serviço disso. Era a primeira vez que a via afirmar sua vocação." (VIDAL, 2012, p. 133) O desaparecimento de Vicky, no ano de 1976, portanto, será a nossa referência para outros indícios de tempo presentes na obra.

Depois do fatídico dia 26 de junho daquele ano, mais precisamente três meses depois, a narradora nos conta que pegou um ônibus na rodoviária e seguiu "[...] um trajeto incerto para o norte.” (VIDAL, 2012, p. 89) Não sabemos com precisão a sua idade no momento da partida, mas sabemos, pelas suas palavras, a idade de seu pai quando da mesma forma resolveu partir da argentina no ano de 1956: "O meio da vida dele terá sido em 1956? Ele estava então com quarenta anos e talvez tenha pensado que era hora de partir a vida em dois." (VIDAL, 2012, p. 124), bem como a idade com que veio a falecer: "[...] ele morreu muito velho, quase com noventa e cinco anos." Se o seu pai havia a abandonado em 1956, se a narrativa se desenvolve por meio da escrita nos cadernos encontrados pela narradora no antigo apartamento de seu pai os quais, cronologicamente falando, estão sendo preenchidos até o final coincidente com o final do romance, e se o ano de desaparecimento de Vicky é 1976, concluímos que a narradora deva ter por volta de 65 anos, já que nunca mais o havia encontrado, mesmo depois indo residir no mesmo país que ele. Tal idade é coerente à informação que surge no capítulo 18, pois apenas a essa altura ficamos sabendo que a narradora é uma senhora aposentada que, após problemas ortopédicos, volta a praticar natação, ao mesmo tempo em que percebe a sua casa invadida por acessórios presentes em sua nova rotina: 
A casa teve que dar espaço para chinelos de borracha, toalha, maiô, óculos, tudo o que entra e sai diariamente da bolsa úmida; e enquanto se transladam os objetos a sua umidade clorada também entra em movimento com um roteiro próprio da porta à área, da área ao banheiro, para desaguar no ralo junto com a espuma de sabão. (VIDAL, 2012, p. 85).

A rotina da natação é conjugada à rotina da escrita no avesso do diário paterno, a narradora, assim, parece agir como uma espécie de água clorada, fora do ambiente natural, que invade a ordenação do território masculino paterno, esse pai que era um homem organizado:

[...] meu pai que tinha sua maneira de produzir repetição com pesos de papel, coleções de selos e moedas, pilhas de cartas, livros organizados alfabeticamente. Esse era o mundo proibido para mim. O mundo que importava para ele e ao qual dedicava uma ordem especifica. Como nestes cadernos. Terá ele imaginado que um dia eu os profanaria? (VIDAL, 2012, p. 85-86).

Mas antes o romance começa por duas personagens que nos são apresentadas no prólogo: a narradora/protagonista e R, seu então namorado. Ao iniciarmos a leitura de Mar $a z u l$, as personagens se deslocam em meio aos fragmentos de diálogos de maneira quase dissimulada, uma vez que não conseguimos, num primeiro momento, saber quem são. Contudo, percebemos que se trata de duas amigas conversando e discutindo o desencadear de um relacionamento, no qual uma delas está submetida, cujo aspecto abusivo se sobrepõe a qualquer sinal de envolvimento amoroso. Mais tarde, descobrimos que se trata da narradora, Vicky e R também por incursões ao longo dos capítulos que fazem alusão ao diálogo de abertura, como já havíamos visto que ocorrera com relação à ditadura ou aos espaços em que as personagens transitavam ao longo de toda a obra.

Valendo-nos dessas constatações, percebemos a protagonista enquanto alguém à parte, como ela mesma coloca em diálogo com Vicky:

- Nem vem, você sabe que eu nunca fiz parte.

- Porque você não se esforça.

- Porque eu não tenho nem pai nem mãe. (VIDAL, 2012, p. 11)

Essa primeira afirmação sua é emblemática no sentido de caracterizá-la enquanto uma pessoa fragilizada e, por vezes, até mesmo "tapada", como diria a amiga no primeiro diálogo apresentado: “- Como é que você pode ser tão tapada?” (VIDAL, 2012, p. 7) Depois, num outro momento e outro fragmento, a mesma protagonista afirma que nunca falou com ninguém sobre as coisas mais importantes, “[...] acho que eu não conheço ninguém e que ninguém me conhece.” (VIDAL, 2012, p. 12). Faz-se necessário destacar que, mesmo não sabendo com exatidão a sua idade, deduzimos que não esteja longe dos 13 anos, mencionado em outro fragmento (visto que não sabemos traçar a cronologia de cada um deles), e em razão disso uma outra característica que pode ser mencionada é a sua maturidade, o que não nos surpreende uma vez da ausência dos pais e também não diminui a sua propensão à dominação de $\mathrm{R}$, pois a maturidade transmitida por meio de seu discurso também deixa espaço para um certo conservadorismo que, em última instância, parece atrair homens como $\mathrm{R}$ ao perceber que encontraria nela um vislumbre de pureza e fácil subjugação. Nesse sentido, todas essas características parecem coadunar para o 
último diálogo apresentado ainda no prólogo, quando lemos então a descrição do crime de estupro transmitida nas próprias palavras de R, silenciando em definitivo a voz da narradora. Sabemos de antemão a explícita tendência de $\mathrm{R}$ para ideais nacionalistas e autoritários quando, ao longo dos diálogos, a narradora conta a Vicky alguns fatos sucedidos a ela quando na presença de $\mathrm{R}$, como o que podemos constatar a seguir:

- [...] Ele trouxe aquele livro do Colégio Militar, sabe?

- Sei, ele anda com aquilo pra cima e pra baixo. [...]

- Ele começou a me mostrar as fotos. O lugar é enorme. Na entrada tá escrito "Ordem, Valor, Glória”. Ele explicou o que cada uma dessas coisas significa. [...]

- Depois me mostrou os cadetes com aqueles uniformes impecáveis, que nem o que ele tava vestindo aquele dia, lembra? [...]

- E tem um monte de fotos dos detalhes do uniforme, tudo tem que estar perfeito, muito pior do que lá no colégio. [...]

- Ai ele começou a falar do sabre, que tem cinco partes e que cada parte significa uma coisa. Ele falou que o punho simboliza a verdade e que no puxador tem o escudo da Pátria. E na lamina tem escrito um verso do hino nacional.

- Você vai ficar me dando uma aula também?

- De repente, ele levantou e fez o gesto como se estivesse empunhando o sabre e começou a recitar umas frases que diziam alguma coisa do tipo "melhor morrer enforcado do que trair a Pátria".

- Que horror.

- E ai eu vi que enquanto ele recitava o negócio dele tinha ficado duro e parecia que a calça ia rasgar. (VIDAL, 2012, p. 31-32)

O interessante a ser destacado nesta fala da narradora é a proximidade com que contextos repressivos se fiam ainda mais irresolutamente à subalternização da mulher. $\mathrm{R}$ não apenas obrigava a narradora a ouvir o que quer que fosse que ele queria dizer como encontrava nela um subterfúgio para colocar em prática seus desejos mais antidemocráticos, sem impeditivos. Assim, não surpreende que o prólogo tenha seu fim determinado por uma narrativa de estupro, que leva a cabo a dominação de R sobre a narradora e que, por conseguinte, ficaria marcada nela para sempre ${ }^{4}$. Segundo Aucía (2011), a implementação da repressão ilegal na América Latina afetou as mulheres de maneira distinta, "entre outras coisas devido ao uso da violência sexual que lhes foi imposta nos CCD, campos, prisões, serviços policiais e militares, etc., nos quais encontravam-se presas ou sequestradas e/ou desaparecidas." (AUCÍA, 2011, p. 31) e tais reflexões se fazem imprescindíveis para a contextualização do enredo a partir do momento que vemos três mulheres reféns de uma mesma política ditatorial. Voltando ao trecho em que se passa o estupro propriamente, temos uma marca de diferenciação também resultante desse lugar de fala em que se encontram as personagens: "eu quero o melhor pra você", diz R, "eu quero te ensinar um monte de coisas, você é tão burra, mas eu vou te ensinar, tudo, tudinho." (VIDAL, 2012, p. 40). O que R quer ensinar, partindo da noção de mulheres enquanto encarrega-

4 Eis as últimas linhas do último fragmento: "Para de chorar e se mexe, já estou quase acabando, eu não quero te machucar, você sabe, eu quero o melhor pra você, eu quero te ensinar um monte de coisas, você é tão burra, mas eu vou te ensinar, tudo, tudinho, mas agora se mexe, vamos, mexe um pouco essa bunda, que gostosa, bem fechadinha, isso, bem apertadinha, só pra mim, só minha, do jeito que eu mandar, assim, isso, não chora, não chora, assim, se mexe assim, minha putinha, assim, assim, agora eu estou em você pra sempre." (VIDAL, 2012, p. 40, grifo nosso). 
das da transmissão da cultura ${ }^{5}$, não deixa de ser a perspectiva da Ordem, do Valor e da Glória que, sabemos, pode ser traduzida por submissão (das mulheres), moralidade (dos homens) e triunfo (do autoritarismo).

Uma última personagem a ser pormenorizada é o pai da narradora, autor dos diários que ela profana, como já dito acima. Para além do fato de tê-la abandonado, partindo em direção à Brasília, cujo projeto ele ajudará a dar forma, percebemos que por vezes haviam tido um convívio bastante próximo, no sentido de sua ausência, para a narradora, significar mesmo um aprendizado. Um dos primeiros traços que os aproxima é o hábito da anotação, mencionado logo no primeiro capítulo:

Meu pai decidiu anotar o que estava perdendo nestes cadernos, que hoje são minha herança. A memória precisa se tornar um armazenamento visivel. Mesmo longe dele devo ter intuído isso, porque desde cedo adquiri também o hábito da anotação. Como ele, acumulei muito papel que está guardado em armários, caixas e gavetas. (VIDAL, 2012, p. 42)

Também fica clara a predileção do pai, assim como da narradora, pela água, pelas piscinas, pelo mar: "Eu sou a única menina nessa piscina enorme, de azulejos azuis encardidos, alguns partidos, onde meu pai e eu ficávamos à espera de que as horas passassem, porque por algum motivo ele só me levava à piscina em pleno inverno." (VIDAL, 2012 , p. 54). Talvez este algum motivo tenha a ver com os ares sombrios já instaurados em território argentino pelos militares. Num dos diálogos contidos no prólogo, quando descobre que R havia sido expulso do Colégio Militar, a narradora começa: "Meu pai não ia gostar", ao que Vicky responde, "Acho que não", e recebe a réplica, "Bom, mas ele foi expulso." (VIDAL, 2012, p. 9). Ou seja, ele não ia gostar de saber que a filha tinha um namorado que frequentava Colégio Militar, em plena ascensão do autoritarismo no Cone Sul, embora isto sejam apenas deduções. Fica a impressão de que à filha não foi dada a chance de compreender quais eram as atividades de seu pai e é justamente esta a origem das inquietações que a acometiam: "De que lado estava a viagem para ele? Da fuga ou da completude? Ele podia ter ficado?" (VIDAL, 2012, p. 94). Mais adiante, ainda sobre fugas e partidas, vemos algumas descrições que incorporam a atmosfera repressiva aos movimentos que se propunham opositores ao Estado, em meio às incertezas que só a nossa protagonista poderia admitir conhecer:

Meu pai estava sempre de partida. Porque antes de vir para cá ele foi para "o sul” e depois para "o interior". Ele dava nomes assim, vagos, aos lugares e às vezes indicava datas.

[...]

Quando eu o via aparecer era como um milagre porque tudo era tão incerto. Quem sabe ele tivesse morrido. Quem sabe um acidente, a prisão, um sequestro. Havia em meu pai algo de clandestino. Ainda ele tivesse um trabalho regular e saísse todas as manhãs para cumpri-lo. Ainda que sua vida paralela de tradutor não chegasse a torna-lo um excêntrico. Havia algo nos seus amigos e nas reuniões noturnas sob nuvens de fumaça; na forma como falavam da situação do país com prognósticos soturnos; e baixavam a voz como conspiradores, enquanto preparavam uma jogava de xadrez. (VIDAL, 2012, p. 104-105)

5 Como aponta Aucía (2011), "Enquanto que as mulheres são representadas fundamentalmente como mães, encarregadas da transmissão da cultura, estabelece-se uma conexão significativa entre masculinidade, militarização e conflito armado." ["Mientras las mujeres son representadas fundamentalmente como madres, encargadas de la transmissión de la cultura, se establece una conexión significativa entre masculinidad, militarización y conflicto armado.” (AUCÍA, 2011, p. 30, tradução nossa)]. 
A partir de descrições tais como as anteriores, podemos deduzir, então, que seu pai fora embora exilado, ao contrário de Vicky que, sem alternativas e pega de surpresa, desapareceu, ambos reféns de um mesmo poder arbitrário que os circundava.

Contudo, passemos agora a um outro tipo de poder que também definiu qual o caminho a ser percorrido pela narradora, podendo ser entrevisto a partir de cada página narrada no verso das folhas dos cadernos deixados pelo seu pai: o poder simbólico da lembrança. Aqui, faz-se imprescindível salientar a estrutura do romance a fim de que se consiga chegar à leitura que propomos. Como já descrito anteriormente, o romance tem em seu começo um prólogo composto por fragmentos de conversas entre a narradora e sua amiga Vicky, sendo que ao final esta mesma composição fragmentária é retomada na forma de epílogo, também a partir de uma conversa entre Vicky e a narradora. Em meio a estes diálogos, então, encontra-se a divisão em capítulos, os quais darão à narrativa tons de realismo mesclados a "rasgos de continuidade", para tomar de empréstimo as palavras de Tamara Kamenszain, e que, em decorrência disso, farão parecer que a narradora se dá o direito, por meio das palavras escritas, de postergar aquilo que realmente deseja dizer, ou até mesmo pensar:

Procrastinação ou 'síndrome do estudante'é o termo que a psicologia clássica utiliza para definir essa atividade que é adiada ao limite, a substituindo por outra mais irrelevante. Então, escrever todos os dias e muito transforma-se aqui justamente na atividade irrelevante que ajuda a adiar a verdadeira escritura. (KAMENSZAIN, 2017, [n.p.] $)^{6}$

São muitos os exemplos que podemos citar em relação à procrastinação proposta pela narradora de Mar azul, como este apresentado no capítulo 4:

Estou me perdendo. Por sorte já chegou a hora da caminhada da manhã. Tudo poderá ser feito com muita calma. Tempo não me falta. Poderei me trocar. Primeiro tirar o pijama, depois ficar sob a ducha e ao sair secar o cabelo com a toalha. Talvez fiquem alguns fios nela, mas isso não vai me preocupar, porque de tempos em tempos meu cabelo começa a cair, mais agora, com esta idade. (VIDAL, 2012, p. 50)

E a partir dele, é possível indagar: do quê e como ela está se perdendo? Não porque trazemos o excerto de maneira isolada e não teríamos condições, afinal, de averiguar porque a narradora estaria se perdendo, mas porque as linhas que o antecedem indicam uma perda de orientação prática necessária que a impeça de se ver "submersa na lembrança". "Sem forças para resistir, passei a manhã toda submersa na lembrança." (VIDAL, 2012, p. 55), é como tem início o capítulo 6. Nesse sentido, ao sairmos do prólogo que se finaliza por meio da narrativa de estupro, é como se mergulhássemos junto com a narradora neste vasto mar de lembranças que a mantém em estado de alerta constante. Indícios disso se mostram logo na primeira frase do capítulo 1: "Se um daqueles pombos sobre a mancha ensolarada do pátio levantar voo agora me deixarei arrastar pela lembrança [...]" (VIDAL, 2012, p. 41). O uso da palavra arrastar alude, em conjunto com o título

6 “Procrastinación o 'síndrome del estudiante' es el término que la psicologia clásica utiliza para definir esa actividad que se posterga al limite sustituyéndola por otra más irrelevante. Entonces, escribir todos los días y mucho se transforma aquí justamente en la actividad irrelevante que ayuda a postergar la verdadera escritura (...).” (KAMENSZAIN, 2017, [n.p.], tradução nossa) 
da obra, ao movimento das ondas e por essa razão toda a narrativa será marcada por idas e vindas, reflexo da agitação ou calmaria das águas que resultam, para a narradora, numa determinada latência e numa subjetivação permanente, posto que "eu" e mundo acabam por coincidir, conforme já afirmamos acima. Com o intuito de sermos mais objetivos em relação ao mar e seus significados, tomemos como norte este verbete segundo a descrição do Dictionary of Simbols, de Jean Chevalier e Alain Gheerbrant (1996):

[...] o mar é um símbolo do dinamismo da vida. Tudo vem do mar e ao mar tudo retorna. É um lugar de nascimento, transformação e renascimento. Com as suas marés, o mar simboliza uma condição transitória entre a potencialidade sem forma e a realidade formal, uma situação ambivalente de incerteza, dúvida e indecisão que pode acabar bem ou mal. Dai o mar ser uma imagem da morte e da vida simultaneamente. (CHEVALIER; GHEERBRANT, 1996, p. 838) ${ }^{7}$

Se tudo vem do mar e tudo retorna a ele, é notável que a frase que encerra o último capítulo seja: "Do lado de fora agora não havia dúvida: era o mar." (VIDAL, 2012, P. 172), e mais notável ainda é a escolha do posicionamento da narradora em relação ao mar que outrora a deixava submersa. Isso significa que ao longo do romance há uma mudança de perspectiva e essa mudança se explica também por intermédio da simbologia marítima: "Desde que recomecei a nadar a lembrança é mais palpável." (VIDAL, 2012, p. 82), diz a narradora na abertura do capítulo 17 . Ou seja, a partir da prática da natação e do encontro com os cadernos de seu pai e a profanação dos mesmos por meio de sua própria escrita, seu olhar passa a ficar atento ao que transborda o espaço delimitado, ordenado, dos afazeres domésticos, da sua rotina, levando seu corpo à transgressão da ordem, e a partir disso ao alcance de um saber de um movimento incontrolável:

O que estou esperando? Que a vida pode ser uma espera me ocorreu em alguns momentos em que as coisas se tornaram incompreensiveis. Não como foram para meu pai, por uma lacuna crescente na percepção, mas porque não havia como explicar o que certamente poderia ter sido de outro modo se não fosse uma ausência de ação.

A sequência não aconteceu e hoje não me levantei desta cadeira. Não nadei. Não preparei café nem mate. Não lavei os pratos. Não arrumei a cama. Ainda assim a noite está chegando. O planeta girou em torno do seu próprio eixo e me fez chegar aqui. (VIDAL, 2012, p. 88)

Finalmente, como últimos apontamentos desta seção, gostaríamos de destacar dois tipos de movimentos marítimos que se tornam aliados em nossa leitura, à medida em que percebemos sua relevância para uma melhor compreensão das personagens e seus papéis na narrativa. O primeiro deles é o movimento das marés. Sabe-se que o que ocasiona tal movimento é a força gravitacional dos astros, isto é, o Sol e a Lua, fazendo com que as águas do mar movimentem-se diariamente aumentando ou diminuindo sua extensão. O que vemos ao longo da narrativa de Mar azul coincide com um tipo de movimento de maré que, no entanto, tem sua origem em uma oposição às figuras masculinas

7 " $[. .$.$] the sea is a symbol of the dynamism of life. Everything comes from the sea and everything returns to it.$ It is a place of birth, transformation and rebirth. With its tides, the sea symbolizes a transitory condition between shapeless potentiality and formal reality, an ambivalent situation of uncertainty, doubt and indecision which can end well or ill. Hence the sea is an image simultaneously of death and of life." (CHEVALIER; GHEERBRANT, 1996, p. 838, tradução nossa) 
engendradas na obra, o que não deixa em certa medida de ser uma crítica e reflexão à patriarcalização das civilizações ocidentais, visto que os homens rogam para si um certo poder de decisão que, não indiscriminadamente mas sempre discriminado, pode mesmo ser comparado ao poder dos astros, não fosse o fato de que a força gravitacional do Sol e da Lua pode ser tudo, menos arbitrária, ao contrário da dos homens. Nesse sentido, e para corroborar com o nosso argumento, vemos a narradora postular sobre seu pai: "A aprendizagem era então da espera. Eu ficava enquanto ele ia e vinha." (VIDAL, 2012, p. 104) e, junto a essa passagem, passamos a dimensionar as idas e vindas de R por meio das lembranças da narradora, cuja diminuta aparição deixa lugar ao trauma resultante daquele encontro. Não à toa, cada capítulo parece encerrar um dia na vida da protagonista o que contribui com o postulado das marés em relação ao descompasso às figuras masculinas da obra, que representam a ordem, o controle, figurado na metáfora da piscina.

O segundo movimento para o qual gostaríamos de chamar a atenção encontra-se no próprio movimento das ondas, que se movem e alternam em decorrência do vento e da profundidade em que se encontram, a todo instante. Aqui, percebemos menções recorrentes a termos que nos aproximam da "natureza aquática" da personagem. Uma delas, ao final do capítulo 7, diz: "A rotina está posta em marcha e o pensamento finalmente flutua como se não me pertencesse." (VIDAL, 2012, p. 60). Tal flutuar do pensamento é o que rege todo o romance, uma vez que, na proposta da autora, é em direção a este flutuar que ela precisa chegar, ao contrário de submergir ou mesmo se afogar em meio aos pensamentos que a todo momento parecem precisar ser contidos. Com a rotina posta em marcha, o pensamento fica em suspenso; do contrário, o pensamento lhe atinge feito onda e a carrega, para o mais profundo de sua própria subjetivação.

\section{Ditadura e ditaduras}

Para dar início às reflexões desta seção e associá-las mais à frente ao nosso tempo histórico presente, trazemos novamente as palavras de Rita Terezinha Schmidt (2018) as quais nos alertam em relação à dimensão de resistência que se vincula às narrativas escritas por mulheres em contraponto ao sujeito feminino narrado pelos homens:

[...] é preciso deixar claro que falar sobre narrativas escritas por mulheres implica na adoção de um ponto de vista que identifica, no âmago daquelas produções, um projeto consistente de crítica cultural. Independentemente das limitações sócio-culturais [sic] de seu tempo e das diferenças de origem, classe, raça ou nacionalidade, as escritoras desse século têm desencadeado, em suas narrativas, uma série de reflexões e questionamentos sobre os modos como práticas sociais e discursivas colaboraram na definição do sujeito mulher como elemento periférico à cultura. (SCHMIDT, 2018, p. 265)

Em Mar azul, alguns pontos relevantes são levantados a partir da narrativa engendrada pela protagonista para que pensemos em formas que definiram e continuam a definir o sujeito mulher. Num primeiro momento, a lembrança de uma pergunta feita pelo seu pai, “¿no te cansas de hablar?” (VIDAL, 2012, p. 74), a qual evidencia um silenciamento imposto pela figura masculina na vida desta narradora quando ainda jovem, ao passo que agora são as palavras dela que se juntam às palavras dele, não para completá-las e sim para transbordá-las, a fim de que possa dar conta de um relato muito maior e que tem 
por fundamento justamente e certeiramente a figura feminina. É interessante mencionar também, uma vez do uso do verbo "transbordar", que ao final do capítulo 5, quando descreve a lembrança de uma piscina aquecida que ela e seu pai frequentavam (já havíamos citado um trecho deste parágrafo na seção anterior), uma das afirmações constatadas vai ao encontro desta crítica a determinadas práticas sociais e discursivas: "Os homens conversam como se o entorno não existisse." (VIDAL, 2012, p. 54). Em decorrência de tais percepções, o entorno, que pode aqui ser tomado como o feminino, segundo a concepção de backgrounding sugerida por Val Plumwood $(1993)^{8}$, uma vez silenciado, passa a efetivamente não existir:

Ele me acusava: ¿no te cansas de hablar? Essa é também uma lembrança antiga que tenho dele. Como poderia ser de outra forma, talvez fosse minha resposta, se de tal modo minha voz era uma companheira segura. Algo com o que se podia contar. Minha precocidade era denunciada como defeito, e quando ele me imputava não ser capaz de ficar em silêncio nem quando estava sozinha era tal a sua incompreensão que só me restava uma espécie de culpa pela minha opacidade, que com o tempo acabou virando uma timidez irremediável. (VIDAL, 2012, p. 74-75)

No excerto acima, merecem destaque alguns termos que por séculos regem o imaginário feminino por conta de processos de socialização diferenciados: precocidade e culpa. Poderíamos unir a eles ainda um outro trecho, contido no capítulo 9, em que a protagonista revela o seu trato com o medo:

8 "Uma das formas mais comuns de negação da mulher e da natureza é o que chamarei de backgrounding, o tratamento para com elas enquanto fornecedoras de pano de fundo para uma esfera dominante de causa e realização conhecidas e que está em primeiro plano. [...] O backgrounding e a instrumentalização da natureza e da mulher encontram-se paralelamente unidos. Para as mulheres, o seu status de pano de fundo e instrumentalização enquanto natureza não necessariamente precisa vir explícito, uma vez que ele estrutura seus principais papéis tanto na esfera pública quanto na privada. As mulheres são sistematicamente colocadas como pano de fundo e instrumentalizadas enquanto donas de casa, enfermeiras e secretárias (PRINGLE, 1998) como colegas e colegas de trabalho. O seu trabalho em papéis tradicionais é também sistematicamente omitido aos olhos do sistema econômico (WARING 1988) e não é levado em conta quando a história do que é importante na história da humanidade e da cultura é contada. Tradicionalmente, as mulheres são "o meio" [grifo nosso] - elas fornecem o meio e as condições em oposição ao lugar onde 'as conquistas' dos homens figuram, mas o que elas fazem não é em si mesmo levado em conta enquanto conquista (Irigaray 1985a, Le Doeuff 1977). As mulheres estão vulneráveis ao backgrounding mesmo quando elas escapam de seus papéis tradicionais [...], mas são mais fortemente colocadas como pano de fundo ao assumirem os papéis tradicionais, em especial o papel de mães." (PLUMWOOD, 1993, p. 21-22) [“One of the most common forms of denial of women and nature is what I will term backgrounding, their treatment as providing the background to a dominant, foreground sphere of recognised achievement or causation. [...] The backgrounding and instrumentalisation of nature and that of women run closely parallel. For women, their backgrounded and instrumental status as nature does not usually need to be explicit, for it structures their major roles in both public and private spheres. Women are systematically backgrounded and instrumentalised as housewives, as nurses and secretaries (PRINGLE, 1998) as colleagues and workmates. Their labour in traditional roles is also systematically omitted from account in the economic system (WARING 1988) and omitted from consideration when the story of what is important in human history and culture is told. Traditionally, women are "the environment" [grifo nosso] - they provide the environment and conditions against which male 'achievement' takes place, but what they do is not itself accounted as achievement (Irigaray 1985a; Le Doeuff 1977). Women are vulnerable to backgrounding even when they step outside their tradicional roles [...], but are most strongly backgrounded in their traditional roles and especially in their roles as mothers." (PLUMWOOD, 1993, p. 21-22, tradução nossa)]. 
No que eu pensava naquela época? Eu tinha muito medo. Eu tinha medo de que ao sentar no pátio do colégio minha calcinha aparecesse. Eu tinha medo da cara que fazia quando ria com sinceridade. Eu tinha, quase sempre, medo de ser inadequada. Ao tentar me lembrar quando foi que isso começou, não encontro registro. Se procuro na memória uma lembrança de algum gesto que poderia se situar na origem desse estado de alerta em que eu vivia, minha mente fica oca. (VIDAL, 2012, p. 63)

Essa união de tais substantivos, concomitantemente agora à frase "[...] minha voz era uma companheira segura", como transcrita acima, remete-nos ao estupro cometido por R no prólogo do romance cuja descrição prescinde inclusive da voz da narradora. Remete-nos também às palavras de Virginie Despentes (2016) que reitera: “A mística masculina é construída como sendo naturalmente perigosa, criminosa, incontrolável por natureza.” (DESPENTES, 2016, p. 42) ou ainda à afirmação de Ruth Silviano Brandão (2004) de que “"[...] da palavra cassada as personagens femininas têm a vida cassada, de tal forma elas interiorizam uma linguagem que não é a sua própria, mas uma linguagem autoritária que as reduz inconscientemente ao silêncio." (BRANDÃO, 2004, p. 48), silêncio este que ao longo do romance é atravessado por essa "natureza aquática" da narradora que enseja um arrebatamento de sua atual condição, fazendo com que os papéis se invertam e ela possa, enfim, assumir o controle de sua história passando literalmente por cima da história de seu pai feito maré-cheia. Uma história que, segundo os cadernos que ela têm em mãos, deliberadamente a excluiu: "Mas ele não fala daquele passado e talvez seja isso o que mais me obstina. Como pode haver tal vazio? Por que foi que ele me apagou?" (VIDAL, 2012, p. 79)

Dessas constatações, surgem então algumas aprendizagens descritas pela narradora: a aprendizagem do silêncio (p. 75), a aprendizagem da solidão (p. 104) e a aprendizagem da espera (p. 104), todas elas em decorrência de atitudes impostas por essa figura masculina que mesmo ausente ainda assume contornos de presença inquestionável: a de seu pai. Assim, é possível também pensar nas aprendizagens enquanto modelos de conduta cuja adaptação parte do princípio de se moldar a algo, mas à medida que avança por sobre as lembranças, acaba motivando um processo de destruição que as dessacraliza e, portanto, acaba por libertá-la. Isto posto, é também com a aprendizagem do silêncio que ela se depara ao ter contato com os cadernos do pai, embora o silêncio literal venha no formato de enfermidade ao passo que o verdadeiro silenciar tome forma a partir da deliberada exclusão da filha de "seu entorno". A partir daí, vemos também novos traços para a aprendizagem da espera e da solidão, fazendo com que em relação à primeira não se tenha mais nada a ser esperado, e em relação à segunda que a solidão define a sua história, da qual ela se apropria por meio da própria escritura nos verso das anotações de seu pai. Ainda, se por meio das lembranças descritas pela protagonista entendemos a narrativa proposta por ela enquanto maré, essa percepção traz consigo também a ironia de os homens encontrarem-se numa piscina agindo "como se o entorno não existisse", isto é, ainda que seu ser/estar no mundo encerre algum tipo de universalidade pretendida por eles, tal universalidade não passaria de um delírio, pois não haveria naquela situação nada mais bem delimitado. A piscina, então, ao mesmo tempo em que simboliza o controle, simboliza também o cerceamento da margem e, nesse sentido, se o sujeito mulher é dado "como elemento periférico à cultura", o sujeito homem é dado como elemento central de um nada que apenas ele reconhece como universal, visto que uma piscina jamais daria conta de um oceano inteiro quando este se propõe a invadi-la. 
Mas relembrando que a obra é narrada também com base na memória da narradora em tempos antidemocráticos emergidos em seu país de origem, a presentificação de sua escrita arrasta-nos por outros lugares que não podem ser esquecidos, tal como a preocupação da narradora no epílogo que finaliza o romance:

_ Você acha que eu vou esquecer?

- Acho que não.

- Então o que é que eu faço?

- Eu não tenho resposta pra tudo, tá?

- Mas você é melhor do que eu nessas coisas.

- Acho que não tem nada pra fazer.

- A vida continua.

- Não é bem isso.

- Pois é, hoje quando sai na rua achei que tudo tinha uma normalidade tão esquisita. (VIDAL, 2012, p. 173)

Em vistas disso, reservamos estas últimas considerações para que possamos desdobrar do universo ficcional proposto por Vidal - em que ditadura militar, patriarcalismo e o desejo de controle por parte dos homens se unem -, uma (des)continuidade muito próxima de nossa própria trajetória brasileira enquanto nação que se quer democrática, sem conseguir, no entanto, estabelecer rupturas com essas ausências-presenças do passado. Sobre isso, Eurídice Figueiredo (2017) aponta:

No Brasil não se cultiva a memória política porque a anistia significou amnésia, o país se recusa a enfrentar seu passado, a rever os crimes cometidos, a expor as atrocidades perpetradas por um regime de exceção. Enquanto houver esse "vácuo de justiça” (FUKS, 2016), ou seja, enquanto vigorar essa lei iníqua que perdoou os torturadores e os assassinos, o Brasil não ousará olhar para seu passado, continuará sendo um país desmemoriado, ou, como diz, B. Kucinski, um país que sofre de Alzheimer. (FIGUEIREDO, 2017, p. 26)

Para além da questão de memória e memórias que pode ser suscitada por essa última citação, ao pensarmos em "Ditadura e ditaduras" estamos nos referindo, sim, ao regime argentino e ao regime brasileiro enquanto contextos repressivos distintos em suas próprias especificidades, mas pensamos também nas nuances ditatoriais que por vezes imperam ainda hoje, 33 anos findo o regime militar que deixou para trás apenas medo e angústia, e para frente, incerteza e risco. Pensamos também numa forma de poder há tempo demais sendo exercida e que tem como procedimento, assim como analisado na narrativa de Mar $a z u l$ proposta pela narradora-protagonista, o silenciamento e o medo imposto à condição feminina do signo mulher: o patriarcado, "um contrato entre homens, cujo objeto são as

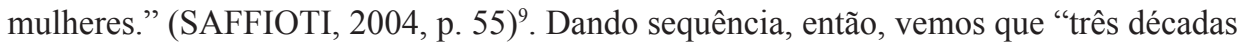
depois do fim da ditadura, a polícia militar brasileira continua torturando e matando os cidadãos vulneráveis, como aconteceu com Amarildo, que se tornou o ícone da vítima da polícia." (FIGUEIREDO, 2017, p. 39). Isso porque

9 Saffioti continua: "A diferença sexual é convertida em diferença política, passando a se exprimir ou em liberdade ou em sujeição. Sendo o patriarcado uma forma de expressão do poder político, esta abordagem vai ao encontro da máxima legada pelo feminismo radical: "o pessoal é político"." (SAFFIOTI, 2004, p. 55 , grifo da autora) 
Eles permanecem aí, sorrindo — em reuniões regadas a bom uísque, sorrindo — diante das câmeras de televisão, sorrindo - de terno e gravata, sorrindo. Parecem felizes, diriam uns, estão de bem com a vida, pensariam outros, têm belas lembranças, concluiriam então. Sem dúvida! Cada vez que um deles se olha no espelho, preparando-se para aparecer em público, uma súbita alegria o invade. É um homem impune, e sempre que lembra disso ele sorri. Sorri diante do nosso esquecimento, sorri diante da perplexidade daqueles poucos que ainda se recordam, que ainda sofrem. Sorri por todos os sorrisos que roubou. (DALCASTAGNE, 1996, p. 15)

Mas quem são eles, afinal? Dentre outras circunstâncias para as quais conduziríamos a mesma pergunta, talvez a que mais se exige uma resposta hoje venha do dia 14 de março deste ano, dia em que a $5^{\text {a }}$ parlamentar mais votada na cidade do Rio de Janeiro, Marielle Franco, foi executada com quatro tiros na cabeça. Mulher, negra, lésbica e não por acaso, nascida no Complexo da Maré, um conjunto de favelas localizado na zona norte carioca, Marielle era crítica ferrenha dos abusos cometidos por policiais em serviço e execuções extrajudiciais, principalmente com relação à intervenção federal que tomou conta do Rio de Janeiro em fevereiro de 2018, de cuja comissão para o monitoramento ela fazia parte. Os assassinos? Ainda que a polícia aponte suspeitos, já se foram 137 dias sem que alguém seja criminalizado pelo assassinato de uma vereadora eleita. É disso que precisamos também lembrar. E que a maré, quando sobe, vem cheia e arrasta tudo pela frente, destrói deixando um rastro de evidências que estiveram o tempo todo ali, mas precisavam ser viradas do avesso para que conseguissem ser notadas. Precisavam se impor sobre a tinta da caneta deles, assumindo um descontrole controlado de si e um controle que descontrola o outro, a ponto de ver surgirem barreiras, bloqueios, impedimentos... e até mesmo uma trincheira simplesmente sobreposta. Marielle, assim como nossa protagonista, é ela também mar que invade em contraponto à latência de uma piscina aquecida com suas bordas intactas e seu masculino bem protegido. Marielle é a força que desborda porque sua aprendizagem do silêncio não se cumpriu e a da solidão acabou tornando-se compartilhada. Logo, são essas várias pequenas solidões que pouco a pouco se deixam elevar por conta de seu alcance marítimo e se desprendem de um fundo oceânico que não mais lhes pertence porque elas são o todo da onda, e não apenas a areia que se desprende do chão em função de um movimento concêntrico.

Bem na verdade, as mulheres são o todo oceânico de uma potência que começa maré, mas vira tsunami, numa revolta que só constrói quando acabada a destruição, embora as frentes constantemente multipliquem-se e seja preciso invadir cada uma delas. Seja preciso lembrar de invadir. Seja preciso lembrar. "Eu te conto e você não esquece." (VIDAL, 2012, p. 12).

\section{Referências}

AUCÍA, A. Género, violencia sexual y contextos represivos. In: AUCÍA, A. et al. Grietas en el silencio: Una investigación sobre la violencia sexual en el marco del terrorismo de Estado. Rosaio: Cladem, 2011, p. 26-67.

BRANDÃO, R. S.; BRANCO, L. C. A mulher escrita. Rio de Janeiro: Lamparina Editora, 2004. 
DÖLL, Karine M. e PACHECO, Keli C.

CHEVAlIER, J.; GHEERBRANT, A. The Penguin Dictionary of Symbols. England: Penguin Books, 1996.

DALCASTAGNE, R. O espaço da dor: O regime de 64 no romance brasileiro. Brasília: Editora Universidade de Brasília, 1996.

DESPENTES, V. Teoria King Kong. São Paulo: n-1 edições, 2016. Trad. Márcia Bechara. DI LEONE, L. Poesia e escolhas afetivas. Rio de Janeiro: Editora Rocco, 2014.

FAUSTO, B.; DEVOTO, F. J. Brasil e Argentina: Um ensaio de história comparada (1850-2002). São Paulo: Ed. 34, 2004.

FIGUEIREDO, E. A literatura como arquivo da ditadura brasileira. Rio de Janeiro: 7 Letras, 2017.

KAMENSZAIN, T. Una intimidad inofensiva - los que escriben con lo que hay. (Ebook) Buenos Aires: Eterna Cadencia Editora, 2016.

PLUMWOOD, V. Feminism and the Mastery of Nature. Nova York: Routledge, 1993.

RANCIÈRE, J. A partilha do sensivel: estética e política. São Paulo: EXO experimental org.; Ed. 34, 2009. Trad. Mônica Costa Netto.

SAFFIOTI, H. I. B. Gênero, patriarcado, violência. São Paulo: Editora Fundação Perseu Abramo, 2004.

SCHMIDT, R. T. Descentramentos/Convergências: ensaios de crítica feminista. Porto Alegre: Editora da UFRGS, 2017.

VIDAL, P. Mar azul. Rio de Janeiro: Rocco, 2012.

Recebido em: 30/07/2018 Aceito em: 11/09/2018 